\title{
Sınıf Öğretmenlerinin Vicdan Algısı
}

\author{
Mehmet DEMİRKOL ${ }^{1}$, Durmuş KILIÇ²
}

\author{
1 Arş.Gör.Dicle Üniversitesi, Ziya Gökalp Eğitim Fakültesi,Temel Eğitim Bölümü mexeme@gmail.com \\ ${ }^{2}$ Prof.Dr.Atatürk. Üniversitesi, Kazım Karabekir Eğitim Fakültesi,Temel Eğitim Bölümü dkilic@atauni.edu.tr
}

\section{DOI: http://dx.doi.org/10.14582/DUZGEF.1849}

\section{ÖZ}

$\mathrm{Bu}$ araştırmanın amacı sınıf öğretmenlerinin vicdan algısını belirlemektir. Nitel araştırma deseni ile şekillenen araştırmanın çalışma grubunu Diyarbakır ili merkez ilçelerinde, 2016-2017 eğitim öğretim yılı güz döneminde görev yapmakta olan 120 sınıf öğretmeni oluşturmaktadır. Verilerin toplanabilmesi için araştırmacılar tarafından geliștirilen yarı yapılandırılmıș görüşme formu kullanılmıștır. Görüșme formları ile elde edilen veriler içerik analizi ile çözümlenmiştir. Araştırma sonucunda sınıf öğretmenlerinin vicdan tanımlarında çeşitlilik olduğu ve vicdanın sosyal, kişisel, ruhsal ve davranışsal olmak üzere dört tema altında tanımlandığı görülmüştür. Ayrıca vicdanın davranış üzerinde biçimlendirici, yönlendirici, engelleyici ve sorgulayıcı etkisi olduğu belirlenmiştir. Vicdanın öğretmen davranışları üzerinde etkili olduğu ve bu kavramın mesleklerinin haz, ölçüt, sorumluluk, yeti, gereklilik, onur, özveri ve meslek ahlakının bir parçası olduğu öğretmen görüșlerinden ortaya çıkan bașka bir sonuçtur. Bununla beraber vicdanın öğretmenlik mesleğinde yer edinmemesi gerektiği görüşüne sahip öğretmenler de dikkat çekmektedir. Son olarak öğretmenlerin vicdan kavramının oluşumunda öğrenciler için rol model olduğu, ayrıca, vicdan kavramının öğretiminde kullanılan yöntem ve tekniklerin bu kavramın öğrenci tarafindan edinilmesinde etkili olduğu belirlenmiştir.

Anahtar Kelimeler: vicdan, mesleki vicdan, sınıf öğretmenliği

\section{The Class Teacher's Perceptions of "Conscience”}

\begin{abstract}
The aim of this study is to determine the conscience perceptions of the class teachers. The study group of the research, which is shaped by a qualitative research design, constitutes 120 class teachers working in the fall semester of 2016-2017 academic year in Diyarbakir province. The semi-structured interview form developed by the researchers was used to collect the data. The date obtained via interview forms were analyzed with content analysis technique. The results of the analysis showed that there is a variation among class teachers views in terms of the definition of conscience and the definitions of the term was grouped under such four themes: social, personal, spiritual and behavioral. Additionally the conscience has been determined to have a formative, guiding, inhibiting and questioning influence on behavior. Another result obtained in this study is that teachers perceive the conscience as a factor influencing their teaching behaviors and a part of their profession's pleasure, criterion, responsibility, competence, necessity, honor, dedication and ethics. However, the existence of perceptions that the conscience should not take place in the teaching profession is also a noteworthy result of this study. Finally the class teachers' views showed that the teachers are accepted as role models for students in the formation of the conscience concept and teaching methods used to teach this concept also have an effect on the formation of this concept in the student.
\end{abstract}

Key words: conscience, professional conscience, classroom teacher

\section{GİRİ̧̧}

Eğitim, toplumlara yön verme ve var olan toplumsal özellikleri ileriki nesillere aktarma yoludur. Bu yön verme ve aktarım, toplumun en dinamik parçalarından biri olan ve eğitimin lokomotifi görevi gören öğretmenler ile gerçekleşir. Toplumun dinamik yapısının ve toplumsal özelliklerinin gelecekte var olmasını sağlayan bu önemli görev öğretmenlik mesleğinin önemini ortaya koymaktadır. Toplum için bu denli önemli olan bu mesleğin, mesleki yetiler barındıracak bireylerden oluşması, eğitim öğretim sürecinin kalitesini belirler. Öğretmenlik mesleğini yerine getirebilmek için, bireylerin ilgili alanın lisans öğrenim düzeyine sahip olmaları ile kanun ve yönetmelikler çerçevesinde belirlenen şartları yerine getirmeleri yeterli görülmektedir. Ancak bu durum öğretmenlik ehliyetine sahip her bireyin öğretmenlik mesleğini layıkıyla yerine getirdiği anlamına gelmez. Çünkü bireylerin aldıkları pedagojik eğitim, alan 
eğitimi ve genel kültür yeterlikleri yanı sıra benimsedikleri ahlaki değerler de, bireylerin mesleki duruşlarını önemli ölçüde etkileyebilir.

Ahlak, bireyin diğer toplumsal düzen kurallarının etkisi olmadan kendini denetlemesi ve kendine hâkim olmasıdır (Usta, 2011). Birey, sahip olduğu ahlak ile insanlarla olan ilişkileri kadar var olan görevlerini değerlendirmesini sağlar (Ulusoy \& Dilmaç, 2014). Söz konusu ilişkilerin oluşumunu, devamını ve değerlendirmesini sahip olduğu ahlaki eylemleri ve vicdanı ile gerçekleştirir. Çünkü ahlakın zorlayıcı gücü insanın vicdanıdır (Köknel, 1996). Ketenci (2008) vicdanı, günlük hayatta karşı karşıya kalınan durumlarda ne yapılması ya da ne yapılmaması gerektiğini söyleyen duygular ve eylem arasındaki bağlantı olarak görmektedir. Ayrıca Kant (2007) vicdanı, bireyin kendi hakkında hüküm vermek değil, aksine kendini uydurma içgüdüsü olarak görürken, Nietzsche (2005) bireyin kendini dişarıya doğru boşaltamayan zalimlik içgüdüsünün içe dönüşü olarak tanımlamaktadır.

Vicdan, kişinin kendi edinimi ve tüm yaptıklarını ahlaki bakımdan yargılama yetisi olarak düşünüldüğünde (İmamoğlu, 2010), bu kavramın bireyin mesleki açıdan tutunduğu ahlaki değerleri şekillendirdiği söylenebilir. Çünkü kamusal otoritenin ya da erk tarafından genel bağlayıcı nitelikte çözümlenemeyen açmaz ya da uyuşmazlıklara bireyin kendi sorumluluğuyla karar verme sürecinde vicdan etkendir (Usta, 2011). Ancak ahlakın göreli olması ve toplumdan topluma değişebildiği gibi farklı grupların benimsediği ahlak kuralları arasında bile farklılıkların bulunabilmesi (Mengüşoğlu, 1965) tek bir vicdan kavramının olmamasına ve bireylerin mesleki süreçte farklı vicdani duruşlar sergilemesine neden olmaktadır.

Öğretmenlik mesleğinin, "tüm mesleklerin meslek adamını yetiştirmesi” bakımından diğer mesleklerden daha önemli ve farklı işlev barındırması (Yeşilyurt \& Kılıç, 2014) ve öğrencilerin etik davranışlarını öğretmenlerinden benimseyip, bu davranışların izinden gitmesi (Karataş, 2013) öğretmenlik mesleğindeki vicdan kavramının önemini ortaya koymaktadır. Bu araştırma ile örgün eğitim sürecinde öğrenciler ile en uzun süre etkileşimde bulunan ve öğrenciler için en uzun soluklu rol model görevi üstlenen sınıf öğretmenlerinin vicdan kavramına ilişkin görüşlerini belirlemek amaçlanmıştır. Bu temel amaç doğrultusunda aşağıdaki sorulara cevap aranacaktır?

- Öğretmenlerin vicdan kavramına ilişkin görüşleri nelerdir?

- Vicdan öğretmenlerin davranışları üzerinde nasıl bir etki yaratmaktadır?

- Vicdanın öğretmenlik mesleğindeki yeri nedir?

- Öğrencilerde vicdan kavramının oluşumunda öğretmenin rolü nedir?

\section{YÖNTEM}

$\mathrm{Bu}$ araştırma, nitel araştırma deseniyle şekillenen betimsel bir çalışmadır. Nitel araştırma, varsayımlar ile başlayan yorumlayıcı/kuramsal çerçeve ve sosyal-beşeri bir sorun olarak yöneltilen bir probleme ilişkin bireylerin ya da grupların amaçlarını keşfetmeye yönelik araştırma sorularının çalışılmasına olanak tanır (Creswell, 2013). Ayrıca nitel araştırma, insanların hayatlarını nasıl anlamlandırdıklarını ortaya koymak, anlamlandırma sürecinin ana hatlarını belirlemek ve insanların yaşantılarını nasıl yorumladığını tarif etmeyi amaçlar (Merriam, 2013). Bu kapsamda, sınıf öğretmenlerinin vicdan algılarını, sahip oldukları bu kavrama ilisskin algılarının mesleki ve bireysel davranışlarının üzerindeki etkisi betimlenmeye çalışılmışır.

\section{1. Çalışma grubu}

Araştırmanın çalışma grubunu, 2016-2017 eğitim-öğretim yılı güz dönemi Diyarbakır il merkezinde yer alan dört ilçede (Kayapınar, Bağlar, Yenişehir, Sur) görev yapmakta olan 120 sınıf öğretmeni oluşturmaktadır. Görüşleri alınan öğretmenler araştırmanın modeline uygun olarak basit tesadüfi örnekleme yöntemi ile seçilmiştir. Çalışma grubunun demografik özelliklerine ilişkin verilere Tablo 1'de yer verilmiştir. 
Tablo 1. Araştırmanın Çalışa Grubunu Oluşturan Öğretmenlerin Kişisel Özellikleri

\begin{tabular}{llcc}
\hline Demografik Nitelikler & Gruplar & Öğretmen Sayısı & Yüzde (\%) \\
\hline \multirow{2}{*}{ Cinsiyet } & Erkek & 50 & 41,7 \\
& Kadın & 70 & 58,3 \\
\hline \multirow{2}{*}{ Yaş } & 30 yaş ve daha az & 39 & 32,5 \\
& 31-40 yaş & 30 & 25,0 \\
\multirow{2}{*}{ Öğrenim durumu } & 41 yaş ve üzeri & 51 & 42,5 \\
\hline \multirow{3}{*}{ Çalışma süresi } & Lisans & 113 & 94,2 \\
& Lisansüstü & 7 & 5,8 \\
\hline Toplam & 10 yll ve daha az & 49 & 40,8 \\
& $11-20$ yıl & 32 & 26,7 \\
& $21-30$ yıl & 27 & 22,5 \\
& 31 yil ve üzeri & 12 & 10,0 \\
\hline
\end{tabular}

Yukarıdaki tabloya bakıldığında katılımcıların \% 41,7’sinin erkek ve \%58,3'ünün kadın öğretmenlerden oluştuğu görülmektedir. Yaş değişkenine göre dağılım oranlarına bakıldığında, çalışma grubunun \% 32,5’inin 30 altı yaş alt1,\% 25'nin 31-40 yaş ve \% 42,5'inin 41 ve üzeri yaş aralığında öğretmenlerden oluştuğu görülmektedir. Görüşleri alınan sınıf öğretmenlerinin öğrenim durumlarına göre dağılımlarına bakıldığında, lisansüstü eğitim görmüş olan sınıf öğretmenlerinin tüm çalışma grubunun \%5,8'ini kapsadığ1; geri kalan öğretmenlerin \% 94,2' sinin ise lisans mezunu olduğu görülmektedir. Ayrıca öğretmenlerin \% 40,8'nin 10 yll ve daha az;\% 26,7'sinin 11-20 y1l arası; \% 22,5'nin 21-30 yll arası ve \% 10'unun 31 yıl ve daha fazla mesleki hizmet süresi olduğu elde edilen verilerden anlaşılmaktadır.

\subsection{Veri Toplama Arac1}

Araştırmada verileri elde etmek amacayla araştırmacılar tarafindan geliştirilen ve iki bölümden oluşan yarı yapılandırılmış görüşme formu kullanılmıştır. Görüşme formunun ilk bölümünde, araştırmanın amacı ile görüşme formunun nasıl doldurulacağına ilişkin yönerge ve öğretmenlerin kişisel bilgilerini (cinsiyet, yaş, kıdem, öğrenim durumu ) belirlemeye yönelik sorular yer almaktadır Görüşme formunun ikinci bölümünde ise sınıf öğretmenlerinin vicdan kavramına ilişkin algılarını, bu kavramın öğretmen davranışları üzerindeki etkileri ile öğretmenlik mesleğindeki yerini ve vidan kavramının öğrencide oluşumunda öğretmenin rolünü ortaya çıkarmaya yönelik sorulara yer verilmiştir.

Hazırlanan görüşme formu literatür taraması ve dört alan uzmanından alınan görüşler doğrultusunda hazırlanmıştır. Büyüköztürk (2012) uzman görüşleri ile kullanılacak ölçme aracının kapsam ve görünüş geçerlik durumlarının değerlendirilebileceğinden bahseder. $\mathrm{Bu}$ araştırmada da kullanılan görüşme formunun uygulanabilirliğini ve amaca hizmet etme durumunu belirlemek için veri toplama aracının hazırlanması sürecinde yer alan alan uzmanlarının görüşleri alınmıss, ardından 10 öğretmene ön uygulama yapılmıştır. Uzman görüşü ve ön uygulama sonucunda veri toplama aracının kapsam ve görünüş geçerliği sağlanmış ve uygulamaya konulmuştur.

Gönüllülük esasına dayanan veri toplama süreci, araştırmacılar tarafindan yürütülmüsstür. Bu süre zarfinda araştırmanın önemi ve kullanılan görüşme formunun nasıl kullanılması gerektiği bilgisi çalışma grubuna aktarılmıştır.

\subsection{Verilerin Analizi}

Bu çalışmada elde edilen veriler ve bu veriler altında yatan kavramlar arasındaki ilişkiyi belirlemek için içerik analizi yönteminden yararlanılmıştır. Yıldırım ve Şimşek (2013), içerik analizini birbirine benzeyen verileri belirli kavramlar ve temalar altında bir araya getirip okuyucunun anlayabileceği şekilde düzenleyip yorumlama işi olarak tanımlar. Kumar (2011), içerik analizi yapıllırken öncelikle elde edilen yanıtlardan, yanıtların anlamlarını yansıtan geniş temalar oluşturulması, ardından ana temalara kodların atanması ve yanitların ana temalar altında siniflandirilması ile son olarak temalar ve rapor metinlerinin bütünleştirilmesi gerektiğinden bahseder. Bu araştırmada veriler analiz edilirken aynı yol izlenmiştir. 
Yanıtların ve temaların sinıflandırılması sürecinde Mindjet Mindmanager 2018 programından yararlanılmıştır.

Araştırmanın güvenirliğini belirlemek için uzman görüşünden yararlanılmıştır. Araştırmacılar ve uzman görüşlerinin değerlendirilmesinin karşılaştırılması sonucu elde edilen görüş birliği ve görüş ayrılığ1 sayıları Miles \& Huberman (1994) tarafindan belirlenen ((Güvenilirlik\%si = [Görüş birliği sayıs1 / (Toplam görüş birliği sayısı + Görüş ayrıllğı] X $100>\% 70$ ise güvenilirdir.) ile hesaplanmış ve \% 88’lik bir güvenirlik yüzdesi ortaya çıkmıştır. Ortaya çıkan anlaşma yüzdesi ile araştırma için yapılan kodlamaların güvenilir olduğu söylenebilir. Görüşleri alınan öğretmen sayısının yüzden fazla oluşu ve kimlik bilgilerinin gizliliğinin esas alınmasından dolayı çalışma grubunda yer alan her öğretmen için rapor yazma sürecinde Öğretmen 1,Öğretmen 2...Öğretmen 120. şeklinde kodlamaya gidilmiştir.

\section{BULGULAR}

Bu bölümde,sınıf öğretmenlerinin görüşlerinden elde edilen bulgular yer almaktadır. Veriler nitel veri analiz yöntemiyle kategorize edilip ilgili program yardımıyla şekillendirilerek açıklanmıştır.

\subsection{Sınıf Öğretmenlerinin Vicdan Tanımına İlişkin Bulgular}

Sınıf öğretmenlerinin vicdan tanımına ilişkin görüşlerinden elde edilen bulgulara Şekil 1'de yer verilmiştir.

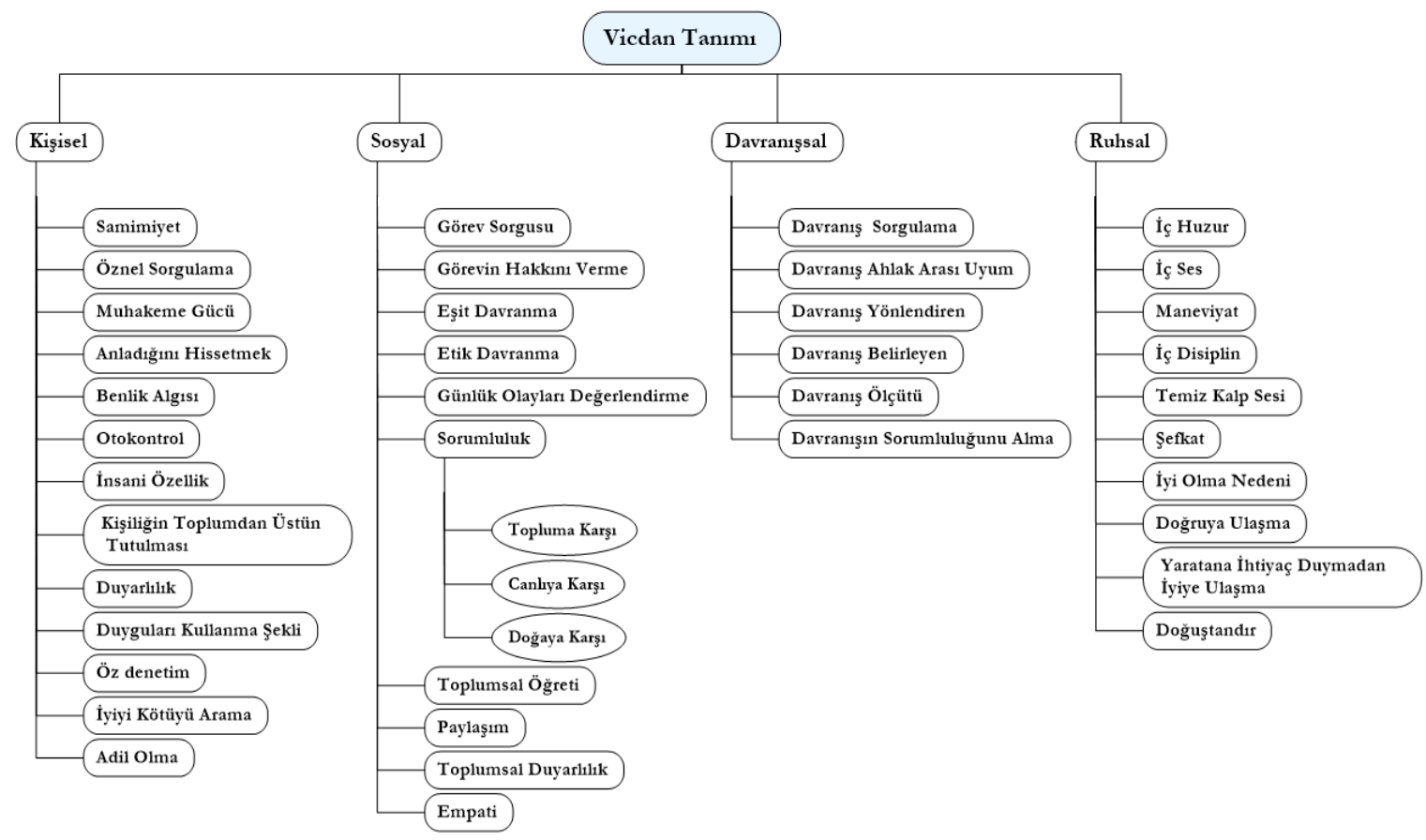

Şekil 1.Vicdan Tanımına İlişkin Öğretmen Görüşleri

Sınıf öğretmenlerinin görüşleri sonucunda vicdan kavramına ilişkin tanımlamalar; Kişisel, Sosyal, Davranışsal ve Rubsal olmak üzere dört tema altında toplanmıştır. Kişisel Tema altında vicdan; samimiyet, öznel sorgulama, mubakeme gücü, anladĭğm hissetmek, benlik algisl, otokontrol, kişiliğin toplumdan üstün tutulması, duyarhhk, bireyin duygular kullanma şekli, öz denetim, iyiyi kötüyü arama ve adil olma olarak tanımlandığ1 görülmektedir.

Sosyal Tema altında vicdan; görev sorgusu, görevin hakkem verme, eşit-etik davranma, sorumluluk, toplumsal ögreti, paylaşım, toplumsal duyarlllı. ve empati kurma olarak sınıf öğretmenleri tarafından tanımlandı̆̆ Şekil 1 'den anlaşılmaktadır.

Davramışsal Tema altında vicdan; davranıs sorgulama, davramış ablak arası uyum, davramış ölçütü, davramıs sorumluluğunu alma ve davranısı yönlendiren duygu olarak öğretmenler tarafindan tanımlanmıştır.

Son tema olan Ruhsal Tema altında ise vicdan; iç huzur, iç ses, maneviyat, iç disiplin, temiz kalp sesi, sefkat, iyi olma nedeni, doğruya ulassma, yaratana ibtiyas duymadan iyiye ulasma ve doğusstan gelen bir dürtü olarak öğretmenler tarafindan tanımlanmıştır. Vicdan tanımıyla ilgili öğretmenlerden alınan görüşlerden bazılarına aşağıda yer verilmiştir: 
Öğretmen 8: Vicdan insanlarda olması gereken bir kavramdir. İnsanlarn otokontrolünü sağlar ve daha doğru kararlar almasina etki eder. İyiyi doğruyu ayırmayn sağladiğ için toplum ilişkilerinin daha sağhlkh olmasım sağlar. Vicdanın toplumsal düzenin sağlamasmda etkili olduğunu düsünüyorum. Anaokullarnnda ve ilkögrretimde çocuklara vicdanl olmann yollarmm ögretilmesi gerektiği kanaatindeyim. Böylece çocuklar kendileri, insanlar ve hayvanlara karşı daha merbametli olurlar. Bu da olumlu bir benlik algısı oluşturur ve daha uyumlu bir yaşam kosulu sağlanmış olur. Vicdan şiddetin engellenmesini sağlar. Bu kavram gençlere mutlaka ögretilmelidir.

Öğretmen 19: Vicdan her şsyden önce empatidir. Bize verilen sorumluluğun üstesinden gelmektir. Görevin bakekın vermektir. Insana topluma yararl olmaktır. Cüzdandan çok insam düsü̈mektir. Özveridir, güler yüzdür, adaletten ayrlmamaktır, yoksulun-gücsü̈əün-çaresiz̨in yararna karnca kararnca derman olmaktır. Dayanıșa-yardımlaşmadır. Güclü olup gücsü̈zün yannda yer almaktr. Ne yazık ki unutulan veya unutulmaya yüz, tutmus, erosyona uğramış bir kavramdir.

Öğretmen 46: Vicdan bir insanın içindeki güvenlik gücü gibi görev yapan, onun davranıslarm biçimlendiren, doğru davranıslar için onu zorlayan, doğru davranmadiğı durumlarda ise onu cezalandiran bir duygudur.

İnsanlarn içine vicdan duygusu yerleștirilebilirse dünyadaki birçok sorunun balledileceğini zannediyorum. Insanoğlu hem kendi cinsine hem hayvanlara hem de bitkilere daha iyi davranacaktır. Vicdan dünyadaki her türlü cezamn, yasağın, kanunun ve mabkemenin üstündedir.

Sınıf öğretmenlerinin vicdana ilişkin tanımlamalarına bakıldığında genel bir tanım ortaya çıkmadığı görülmektedir. Kimi öğretmenler vicdanı toplumsal düzen için gereken ve davranışı etkileyen bir dürtü olarak görürken, kimi öğretmenler ise vicdanı kişisel ya da ruhsal bir durum olarak ele almaktadır. Tüm bu görüşler sonucunda öğretmenlerin vicdanı bireyin kendini ya da toplumsal olayları sorgulayıcı, muhakeme edici içsel ve davranışı yönlendirebilecek itici bir güç olarak gördüğü söylenebilir.

\subsection{Vicdanın Davranış Üzerindeki Etkisine İlişkin Elde Edilen Bulgular}

Sınıf öğretmenlerinden alınan görüşler doğrultusunda vicdanın davranış üzerindeki etkisi belirlenmeye çalışılmışır. Görüşlerden elde edilen verilere Şekil 2'de yer verilmiştir.

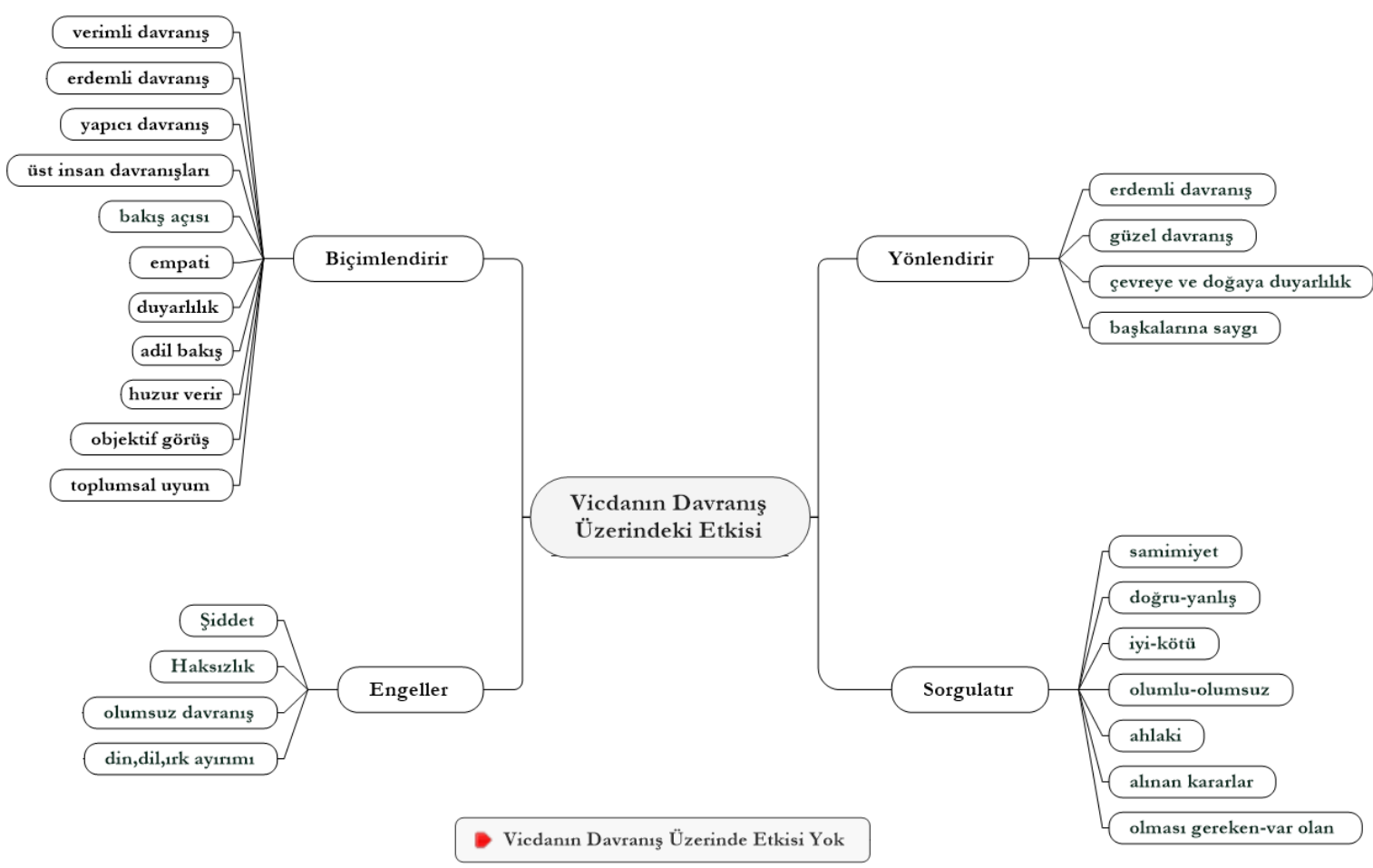

Şekil 2.Vicdanın Davranış Üzerindeki Etkisi

Şekil 2'de vicdanın davranış üzerindeki etkisine ilişkin dört tema oluştuğu görülmektedir. Öğretmenlere göre vicdanın, davranışı Biçimlendirdiği, Engellediği, Yönlendirdiği ve Sorgulattığı sonucuna ulaşılmıştır. Ayrıca vicdanın davranış üzerindeki etkisinin olmadı̆̆ına dair öğretmen görüşlerinin olması 
ortaya çıkan başka bir bulgudur. Öğretmen görüşleri doğrultusunda vicdanın birey davranışlarını, verimli, erdemli, yapıcı, adil ve objektif olmanın yanı sıra empati kurduracak, toplumsal uyum ve duyarllhk sağlayacak şekilde biçimlendirdiği anlaşılmaktadır.

Çalışma grubu olarak görüşleri alınan öğretmenlere göre vicdanın; başkalarnna saygz duyma, gü̈elerdemli davranışlar sergileme, çevreye ve doğaya duyarlllk gösterme konularında davranışları yönlendirdiği anlaşılmaktadır. Ayrıca vicdanın bireyin davranışlarındaki samimiyet, doğru-yanlış, iyi-kötü ya da olması gereken-var olan davramışlar ile alınan kararlar sorgulattı̆̆g öğretmen görüşlerinden çıkan ayrı bir temadır.

Vicdanın bireyin baksızllk yapmasını, siddet uygulamasını, din, dil, ırk ayrmm yapmasinı, olumsuz davramışlar sergilemesini engellediği öğretmen görüşlerinden elde edilen son temadır. Vicdanın bireyin davranışları üzerindeki etkisine dair öğretmen görüşlerinin birkaçı şöyledir:

Öğretmen 5:Davranıslar yönlendirme konusunda vicdan önemli bir etkendir. Sergilediğimiz davranışlar çoğn zaman vicdanımız̨n sesi ile çelissse bile o ses bą̧ noktalarda bastırlsa bile, kişinin dönüp dolaşıp hesap vereceğg, hesaplaşacağg, mubakeme edeceği, öneri alacağr yer iç sesidir yani vicdanıdir.

Öğretmen 89:bana göre vicdan davranıslarmıそ̨ etkiler. Kişinin kendi niyetine ve davranışlarma ters gelen bir durumda vicdan devreye girer. Kişiligine ters gelen olayn vicdan kavramin devreye sokarak kendimizin rabat edebileceğgi sekle sokabiliri:

Öğretmen 98: O davranışı engelleyici ya da devam ettirici bir gü̈s olmakla birlikte bunlardan farkil olarak istenmeyen bir davramıs yapıldiğnnda ic sızlatan ve siz̨i rahatsız. eden bir etki yapar.

Vicdanın davranış üzerindeki etkisine ilişkin öğretmen görüşlerinden çıkan bulgulara bakıldığında; vicdanın insan davranışları üzerinde sorgulayıcı, yönlendirici, biçimlendirici ve hatta engelleyici bir güce sahip olduğu yönünde bir görüş birliğinin olduğu anlaşılmaktadır. Tüm bu bulgulardan yola çıkarak öğretmenlerin, sergiledikleri veya kaçındıkları davranışların gerçekleşme sürecinden, kendi vicdanlarından etkilendikleri sonucuna ulaşılabilir.

\subsection{Vicdanın Öğretmenlik Mesleğindeki Yerine İlişkin Elde Edilen Bulgular}

Vicdanın öğretmenlik mesleğindeki yerine yönelik öğretmen görüşlerinden elde edilen bulgulara Şekil 3'de yer verilmiştir.

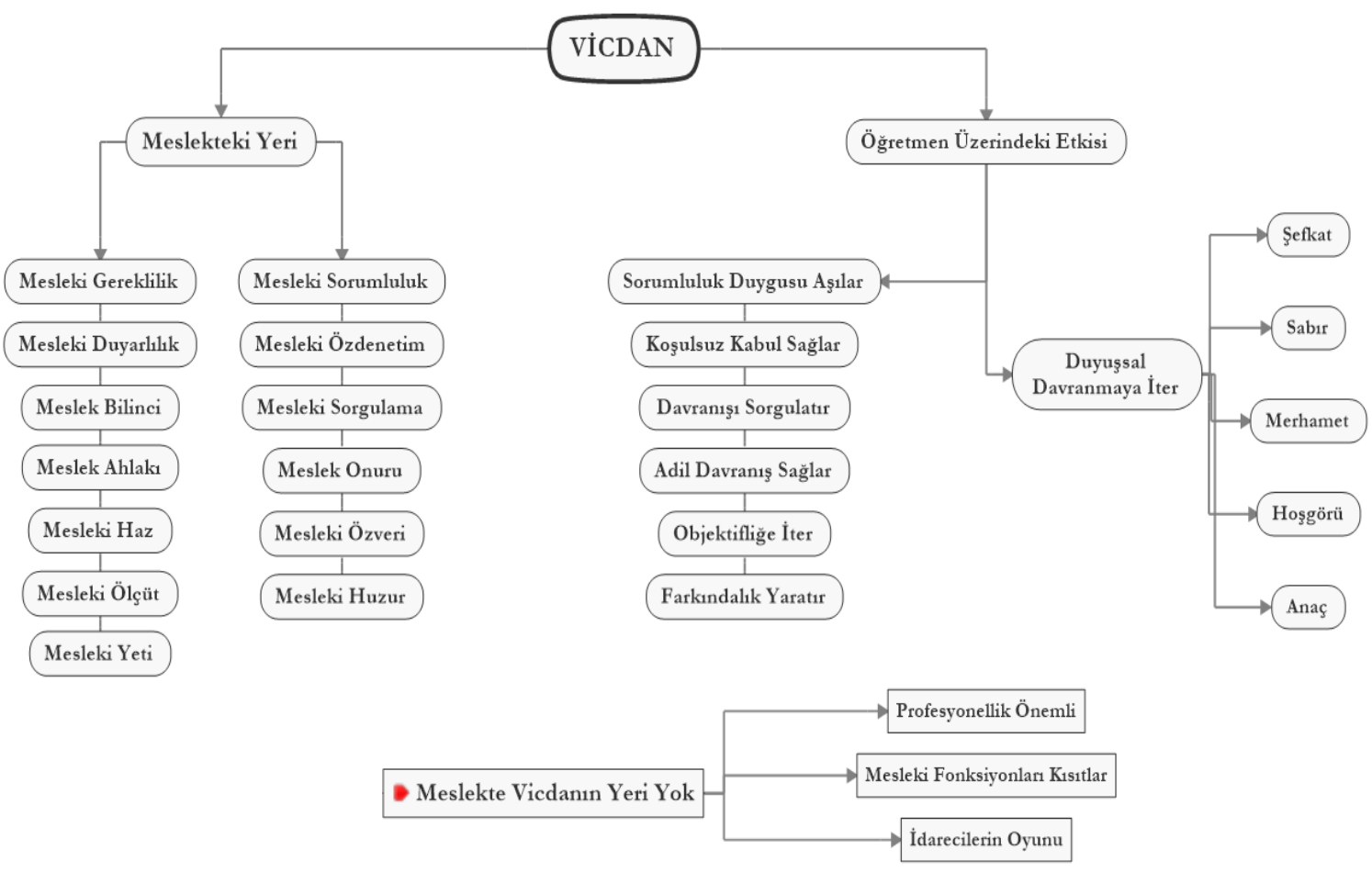

Şekil 3.Vicdanın Öğretmen Mesleğindeki Yeri

Vicdan kavramının öğretmenlik mesleğindeki yerine ilişkin görüşler incelendiğinde, öğretmenlerin vicdana Öğretmenlik. Meslĕgi ve Öğretmen Davramsşlar olmak üzere iki tema altında yer verdiği bulgusuna 
ulaşılmıştır. Ayrıca vicdanın meslekte yeri olmadığına dair görüş bildiren farklı öğretmen görüşleri de yer almaktadır.

Vicdanın Öğretmenlik. Mesleğindeki Yeri teması alında; mesleki gereklilik, mesleki duyarllhk, meslek bilinci, meslek. ablaker, mesleki haz, mesleki ölçü, mesleki yeti, mesleki sorumluluk, mesleki özdenetim, mesleki sorgulama, meslek onuru, mesleki özveri, mesleki huzur kodlarının öğretmen görüşlerinden ortaya çıktığı sonucuna ulaşılmıştır.

Öğretmen görüşleri sonucunda ortaya çıkan bir diğer tema olan vicdanın Öğretmen Üz̧erindeki Etkisine bakıldığında; vicdanın öğretmene sorumluluk duygusu aşıladiğı, koșulsuz kabul-adil davramıs sergilettiği, öğretmen tarafindan yapılan davramışı sorgulattı̆g, objektifliğe ittiği ve farkındalık yarattı̆̆ anlaşılmaktadır. Ayrıca vicdanın öğretmeni duyussal davranmaya ittiği ve bu yüzden vicdanın öğretmene hosgörü, merhamet, şflkat, sabır ve anaç davranışlar sergilettiği bu tema altında yer alan başka bir bulgudur.

Vicdanın Öğretmenlik Mesleğinde Yeri Olmadı̆̆ görüşüne hakim olan ve bu tema altında görüş bildiren öğretmenlerin, profesyonelliğe önem verilmesi gerektiği, vicdanın idareciler tarafindan kullamlan bir oyun olduğu ve vicdanın mesleğgn fonksiyonlarnı kısıtladiğ görüşüne sahip olduğuna öğretmen görüşleri sonucunda ulaşılmıştır. Vicdanın öğretmenlik mesleğindeki yerine ilişkin öğretmen görüşlerinden bazılarına aşağıda yer verilmiştir:

Öğretmen 97: Bir insann şimdiki ve gelecekteki hayatı üzerinde çok önemli bir rolüm olduğunu düşünürüm. İşimi iyi yapmadiğrm zaman vicdan az̧abr çekerim. Aldığrm paranm bana helal olduğınu düş̈̈nmem. Başımı yastığa rahat koymak diye bir deyim var. Isste o vicdandır. İsimi iyi yaptığmmda, sorumluluğumu yerine getirdiğimde rabat uyuyorum. Yapmadiğım zamanlarda ise uyuyamiyorum.

Öğretmen 100: Mesleki olarak vicdanl bir ögrretmenim. Mesleğimi severek yapryorum. Aile ve çocuklarn gözündeki mutluluktan ayr bir haz alyyorum. Özellikle engelli çocuklar ile çalısırken vicdann ayr bir yeri ve önemi olduğunu görüyorum. Her insan gibi ber ögretmende de bu duygunun kişilerdeki yoksunluğn gördülkşe üzülï̈orum. Vicdam olan bir ögrretmen öğrencisi için akademik olarak bir şey yapmasa bile duygusal olarak verdikleri ona büyük kazanctur.

Öğretmen 111: Her mesleğin ve hayatın kendisinin vicdan olgusuna ibtiyaç varder. Esas konu ögretmenlik olduğu için bu konuda ayr bir hassasiyet gerekir. Hak edene hakekm vermekle, hak etmeyene hakkim vermek mecburiyeti arasinda gidip gelen kararsı̨hle esnasinda vicdan devreye girer. Öğretmen olması gerekeni yapmaya çalısırken, olana uygulayacă̆ı süreç öğrencilerin başarısın etkileyecektir. Vicdan ödülde de cezada da devrede olmalidrr.

Yukarıda elde edilen bulgular ve örnek görüşlere göre; öğretmenlerin mesleklerini yerine getirdikleri süreç içerisinde vicdani algılarından etkilendikleri, davranışlarının vicdana göre şekillendiği ve vicdan kavramının kendi mesleklerinde önemli bir yere sahip olduğu görüşü hakimdir. Bununla beraber vicdanın öğretmenlik mesleğinin yerine getirilmesi sürecinde öğretmeni olumsuz yönlendirebileceği, profesyonellikten uzaklaştıracağı düşüncesine hakim öğretmenler de vardır. Ayrıca öğretmende var olan vicdan duygusunun idareciler tarafindan kullanılıp, idarecilerin öğretmenleri istediği şekilde yönlendirebiliyor olması öğretmenleri rahatsız etmektedir.

\subsection{Vicdan Kavramının Oluşumunda Öğretmen Rolüne İlişkin Elde Edilen Bulgular}

Vicdan kavramının oluşumunda öğretmen rolüne ilişkin öğretmen görüşlerinden elde edilen bulgulara aşağıdaki şekilde yer verilmiştir. 


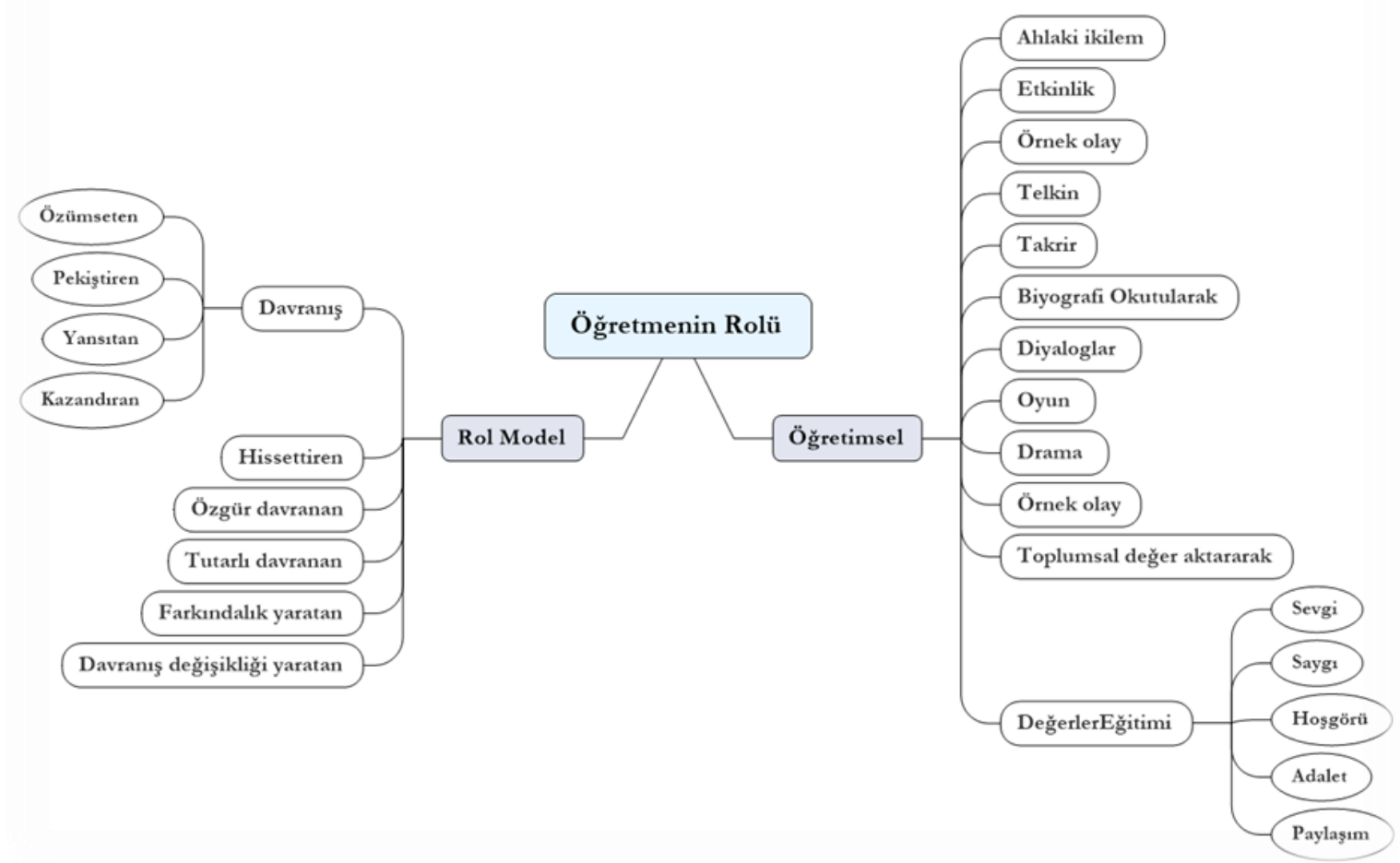

Şekil 4.Vicdanın Oluşumunda Öğretmen Rolü

Sınıf öğretmenlerinin vicdanın oluşumunda öğretmen rolüne ilişkin görüşlerinin Rol Model ve Öğretimsel olmak üzere iki tema altında toplandı̆̆ı görülmektedir.

Öğretmenlerin vicdan kavramının oluşum sürecinde Rol Model olduğu ve bu süreç içerisinde vicdanı

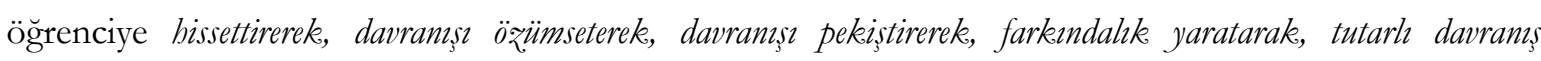
sergileterek, davranış kazandirarak, davramış değişikliği yaratarak bu kavramın öğrencide oluşmasını sağladığı görülmektedir.

Vicdan kavramının öğretiminde, sınıf öğretmenlerinin ögretimsel süreçteki rolünün etkin olduğu görüşü araştırmanın bu bölümünde ortaya çıkan ikinci temadır. Öğretmenin öğretim sürecinde toplumsal değerleri aktarması, drama, örnek olay, takrir tekniklerini kullanması yanında öğrenciyi ablaki ikilemler yaratacak durumlara sokması, biyografiler ile önemli insanlarn bayatm okutmasi, telkinlerde bulunmas1, etkinlikler yapması ve sevgi, sayg1, hoşgörü, adalet, paylaşım gibi değerlerin eğitiminin verilmesi ile vicdan kavramının öğrenciye kazandırabilmektedir. Vicdan kavramının oluşumunda öğretmen rolüne ilişkin görüşlerden bazılarına aşağıda yer verilmiştir:

Öğretmen 7: Ĕger bir ögretmen vicdanh olduğunu ögrencive gösterirse ögrencide bu davramısı ögrretmenden ögrrenecektir. Tipke bilgi aşılar gibi ögretmende vicdanı, ablaki unsurlar ögrrenciye aşlar.

Öğretmen 13: Öğretmen bir ögreticiden çok modeldir. Öğretmen öğrencilere vicdan kavrammı kazandirabilecek ikilemler sunabilir. Örneğin; sınavmız̨n olduğ bir saatte birine yardım etmeniz. gerekirse
- Sinavi mi tercih edersiniz?
○ Birine yardom etmeyi mi?

Öğretmen 113: Bu durum soyut bir husus içerdiğ için bence öğrenciler ile grup çallşmast yaparak bu kişilik özelliğini kazandormak lazım. Özellikle oyun oynatarak ki bu 1.sinf öğrencilerde daha iyi ve etkili olur. Cocuğa karș vicdanl olabiliyorsak ve bir ögretmen isen bunu ögrencilere fark. ettirmek çok önemli olur.

Görüşleri alınan öğretmenlerin geneli, vicdan kavramının oluşum sürecinde öğretmenin rol model olduğunu savunmaktadır. Bunu da eğitim öğretim sürecinde öğretmen davranışlarının öğrenci tarafından birebir gözlenen, taklit edilen ve örnek alınan nitelikte olmasına bağlamaktadır. Ayrıca 
öğretmenin öğrenciyi drama gibi aktfi etkinliklere katması, örnek olaylar ve örnek hayatlar sunması, öğrenciyi sorgulatacak ahlaki ikilemler yaratması, öğretmenin bu kavramı öğrencilere aktarma sürecinde etkin kilan başka bir roldür.

\section{TARTIŞMA ve SONUÇ}

$\mathrm{Bu}$ araştırmada sınıf öğretmenlerinin vicdan kavramına ilişkin algılarının belirlenmesi amaçlanmıştır. $\mathrm{Bu}$ amaç doğrultusunda öğretmenler ile yapılan görüşmelerden nitel araştırma yöntemiyle elde edilen bulgular temalandırılmıştır.

Araştırmanın birinci alt amacında sınıf öğretmenlerinin vicdanı nasıl tanımladıkları belirlenmeye çalışılmıştır. Elde edilen bulgular sonucunda öğretmenlerin tek bir vicdan tanımına sahip olmadıkları, öğretmen tanımlamaları arasında farklılık ve çeşitlilik olduğu görülmüştür. Tanımlamalara bakıldığında öğretmenlerin vicdanı kişisel, sosyal, davranışsal ve ruhsal olmak üzere dört farklı tema altında benimsediği sonucuna ulaşılmıştır. Alan yazın incelemesi sonucunda da tek bir vicdan tanımının olmadığı ve tanımlamalar arasında farkll1ıklar olduğu görülmektedir. Bu durum yapılan araştırmanın vicdan tanımına ilişkin sonuçlarını destekler niteliktedir. Freud'un ahlaki gelişim kuramında vicdanı temsil eden süper egonun insanın davranışlarını ahlaka, toplumsal kural ve beklentilere uygun hareket etmeye zorlaması (Ersoy, 1997), sosyal öğrenme kuramcılarının vicdanı ebeveynler tarafindan konulan ölçütlerin çocuk tarafından içselleştirmesi (Ersanlı, 2005) bu kavramın tek bir tanım altında yer almasını ve mutlak sınırlara sahip olmasını güçleştirmektedir. Çünkü vicdan doğaüstü bir güç tarafından bütünüyle hazır durumda insan ruhuna yerleştirilip tutarlılık gösterme durumu değildir. Bu durum insanlarda aynı nesnel olaylarda (Aym bahçede kirazç̧alan rahip çocuğu ile köylü çocuğunun yakalandıktan sonra bahçe sabibinin sadece rabibi arayıp, çocuğunu cezalandorlmasım istemesi) bile farklı tepkiler oluşturmakta ve insanların yalıngözle bakmalarını engellemektedir (Zulliger, 1996). Araştırma sonucunda sınıf öğretmenlerinin vicdan kavramını farklı temalar altında tanımlamasına, vicdanın toplumsal koşullara ve bireyin içsel algıllayışına bağlı olması sebep gösterilebilir.

Araştırmanın ikinci amacında sınıf öğretmenlerinin görüşlerinden vicdanın davranış üzerindeki etkisi belirlenmeye çalışılmıştır. Çıkan bulgulara bakıldığında vicdanın insan davranışları üzerinde sorgulayıcı, yönlendirici, biçimlendirici ve engelleyici etkisinin olduğu sonucuna ulaşılmıştır. Tüm bu bulgulardan yola çıkarak öğretmen davranışlarının, ortaya çıkmadan önce, gerçekleşme sürecinde ya da gerçekleştikten sonra vicdan süzgecinden geçtiği söylenebilir. Çünkü vicdan insanın dünyayı algılayışında bir ölçüt değil; davranışlarında müracaat edeceği içsel bir kavramdır (Atalay, 2000). Ahlaki bilginin yeterli olmadığı durumlarda ahlaki bilgi ile duyguların birleşiminden olarak ortaya çıkan (Akyürek, 2008) vicdan mekanizması ile birey, karşı karşıya kalınan tek tek durumlarda ne yapılması ya da ne yapılmaması gerektiğini belirler ve eylemi harekete geçirir (Ketenci, 2008). Eylemin gerçekleştĭgi süreçte Öztik-Türer (2015) vicdanı, insan davranışlarını, iyiliğini, kötülüğünü, doğruluğunu, yanlışlığını, haklılı̆̆ını, haksızlığını içsel olarak yargılama gücü, bir oto kontrol mekanizması olarak görürken; Aydın (2003) vicdanı bu davranışlar hakkında hüküm verme işi olarak görür. Kant (2007) bu görüşe karşı olarak vicdanın hüküm verme itkisi değil ahlak yasalarına uyma içgüdüsü olduğundan bahseder. Her ne kadar farklı görüşler olsa da sonuçta kişi kendi vicdanının ürünü olan ahlak ilkelerine uyar ve insanın bir değeri olduğuna inanır (Hatunoğlu, 2003). Bireyde ortaya çıkan davranışların bireysel ilkeler doğrultusunda ortaya çıkması ve her bireyin davranışında vicdanın farklılık gösteriyor olması olağandır.

Araştırmanın üçüncü amacında vicdanın meslekteki yeri incelenmiştir. İnceleme sonucunda mesleki tema altında öğretmenlerin vicdanı, mesleki sorumluluk, özveri, duyarlılık, gereklilik, yeti olarak görmenin yanında mesleğini sorgulayan, mesleki davranışların ortaya konması sürecinde bir ölçüt, bir özdenetim olarak gördüğü ve öğretmen davranışlarını bu yönde etkilediği anlaşılmaktadır. Bu bulgular ışığında vicdanın, öğretmenleri etik davranışlar sergilemeye yönelttiği, öğretmenlik mesleği ile etiklik arasında bağ kurdurduğu söylenebilir. Çünkü diğer mesleklere oranla öğretmenlik mesleği ile etiklik 
arasındaki bağlantının çok daha fazla olması, öğretmenin hangi branşta olursa olsun bazı etik ilkeler doğrultusunda hareket etmesi ve sorumluluklarının ne olduğunu iyi bilmesini zorunlu kılar (Ilgaz \& Bilgili, 2006). Bu da öğretmenin eğitim sisteminin amaçları doğrultusunda öğrencinin geleceğinin inşa edilmesi ve ögrrencinin toplumda yer edinmesi sürecinde önemli rol oynamasina sebep olur. Öğretmenlerin sabırlı, dürüst, güvenilir, yardımsever, hoşgörülü, ön yarg1sız olması, empati kurabilmesi (Yılmaz, 2005), öğrencilere değer vermesi, saygılı olması, görev sorumluluğunun bilincinde olması (MEB, 2017) öğretim sürecinde öğretmenlerden beklenen davranışlarından bazılardır. Tüm bunlanı yaparken öğretmen okulu örgüt (Cinay, 2015), kendini örgüt üyesi olarak görür. Alan yazında özgecilik, nezaket, sivil erdem ve centilmenlik ve vicdanlılık olmak üzere beş boyut altında toplanan (Organ, 1988) ve örgütsel vatandaşlık olarak anılan bu durum; örgüt üyelerinin biçimsel olarak sınırlanmamış, örgüt lehine sonuçlanacak (Karacaoğlu \& Güney, 2010), örgütün işlevlerini verimli bir şekilde yerine getirmesine yardımcı olacak, gönüllülük esasına dayanan davranışlar olarak tanımlanır (Uslu \& Balc1,2012). Örgütsel vatandaşlı̆̆ın vicdanlllık boyutunun, işe devamllık, dakiklik, iş yerinde düzenli çalışma ve dinlenme zamanlarını suiistimal etmeden kullanma (Farh, Zhong \& Organ, 2004), sorumluluk alma (Morrison \& Phelps, 1999), görev bilinci (Özdevecioğlu, 2003), işi kutsal görme (Van Scotter \& Molowidlo, 1996) olarak kabul görmesi araştırma sonuçları ile örtüşmektedir. Bu durum, vicdanın öğretmenleri mesleki hayatları süresince örgütsel vatandaşlı̆̆a yönelttiği sonucunu ortaya koymaktadır. Bunun yanında görüşleri alınan sınıf öğretmenlerin bir kısmı, öznel olan vicdan kavramının kendi mesleki davranışlarını şekillendirebilir veya yönlendirebilir olmasını olumsuz karşılamaktadır. Bu görüşü savunan öğretmenler, öğretmenlik mesleğinin vicdan ile icra edilmesi yerine mesleki gerekliliklerin yerine getirilmesi ve profesyonelce davranılması gerektiği görüşüne sahiptir. Ayrıca vicdanın meslekte yer almaması gerektiğini belirten öğretmenlerin bir kısmı, öğretmenlerin vicdan algılarının idareciler tarafindan kullanılıp duygularının bu yolla sömürüldüğü görüşündedir.

Temel eğitim döneminde yer alan çocuk, yaptığı davranışları sonuçlarına göre değerlendirip, kendisinden beklenen davranışı yapmanın doğru olacağı, bu davranışı yaparak anne-baba, öğretmen ve arkadaşlarının sevgisini kazanacağını, onlar tarafindan takdir edileceğini düşünerek yapar (Can, 2004). Tüm bu davranışları yaparken çocuk, çevresinde var olan yetişkinlerde ve öğretmenlerde gözlemlediği olumlu davranışları benimser ve onlar gibi davranmaya çalışır (Çağdaş \& Şahin, 2002). Aynı durum çocuğun ahlak gelişimi süreçlerinden biri olan vicdan kavramının gelişimi için de geçerlidir. Çünkü çocuk temel eğitimin ilk yıllarında taklitçi; son yıllarında ise duygusal vicdanlıdır (Topbaşı, 2006). Bu yüzden ilköğretim çağındaki çocuk taklitçi yönü ile bilişsel, duyuşsal, sosyal, devinişsel davranışların yanı sıra beğenilen ve saygı duyulan yetişkin davranışlarını da model alarak kazanabilir (Demir \& Köse, 2016). Bu durum ilkokul çağındaki öğrencinin ahlak gelişimi sürecinde yoğun bir etkileşimde bulunduğu öğretmenleri rol model olarak değerlendirmesine sebep olur. Yapılan çalısmalara bakıldığında öğrencilerin kişilik gelişimi ve değerler eğitimi sürecinde öğretmenlerin kendilerini rol model olarak gördüğü anlaşılmaktadır (Demir \& Köse, 2016; Berkant, 2014; Yaşaroğlu, 2014; Kılıç vd. , 2014). Öğretmenler, rol model olma dışında sınıf içinde uyguladıkları yöntem-teknikler ile de öğrencinin ahlak gelişimine olumlu yönde etki edebilmektedir. Bakioğlu \& Tokmak (2009) öğretmenlerin hikaye ve canlandırma yapılabileceği, empati geliştiren yöntemlerin yanında somut örneklerin kullanımının vicdan ve duygulara hitap edilmesini ve eğitime katkısının olacağından bahseder. Temli, Akar ve Şen (2011) tarafindan yapılan çalışmada örnek olay ve rol oynama yöntemlerinin ahlak eğitiminde etkili birer yol olması sonucu bu durumu desteklemektedir. Yapılan araştırmanın son amacına ilişkin olarak, çocuklarda vicdan kavramının oluşum sürecinde rol model olan öğretmen davranışlarının etkili olduğu anlaşılmaktadır. Ayrıca,özellikle değerler eğitiminin öğretim sürecinde öğretmenlerin kullandığı yöntem tekniklerin de etkili olduğu görüşü hakimdir. Ortaya çıkan bu bulgular, alan yazını destekleyen başka bir sonuç olarak ortaya çıkmıştır. 


\section{KAYNAKÇA}

Akyürek, P. G. (2008). İlkögretim din kültürü ve ablak bilgisi derslerinin ögrencilerin ablaki gelisimine etkisi: Koblberg'in ablak gelişimi kuramı açısından bir değerlendirme. (Yayınlanmamış Yüksek lisans tezi). Erciyes Üniversitesi, Kayseri.

Atalay, E. (2000).Vicdan özgürlüğü. İnsan Haklar Yillğğ Cilt 21-22

Aydın. , M. Z. (2003). Ablak ögretiminde örnek olay incelemesi yöntemi. Ankara: Nobel Yayın Dağıtım, s.33

Banks, J. A. (2013). Cokkeültürlü eğitime giriş. (Çeviren: H. Aydın). Ankara: Anı Yayıncılık

Berkant, H. G., Efendioğlu, A. \& Sürmeli, Z. (2014). Değerler eğitimine yönelik öğretmen görüşlerinin incelenmesi. Turkish Studies - International Periodical for The Languages, Literature and History of Turkish or Turkic, 9 (5), 427-440.

Büyüköztürk, Ş. (2012). Sosyal bilimler için veri analiz̧i el kitabı. (17.Baskı). Ankara: Pegem Akademi.

Can, G. (2004). Kişilik gelişimi. İçinde: B. Yeşilyaprak (Ed.), Gelişim ve öğrenme psikolojisi, (ss. 109140). Ankara: Pegem A Yayıncilik. s. 130

Cinay, F. (2015). Illkokul ögretmenlerinin mesleki tükenmişslik düzeylerinin örgütsel vatandaşllk davranıslar arasındaki ilişki. (Yayınlanmamış Yüksek lisans tezi). Okan Üniversitesi, İstanbul.

Creswell, J.W. (2013). Nitel araştrma yöntemleri: bes yaklaşıma göre nitel araştırma ve araștrma deseni. M. Bütün \& S. B. Demir (Çeviri Ed.).Nitel çalışma tasarımı. (ss.42-67). Ankara: Siyasal Kitapevi. s. 64

Çağdaş, A. \& Şahin, Z. S. (2002). Çocuk ve ergende sosyal ve ablak gelişimi, Ankara: Nobel Yayın Dağıtım. s. 42

Ersanl, K. (2005), Davranışlarmı gelişim ve ögrenme, Samsun: Eser Matbaası.

Ersoy, N. M. (1997). Adalet alannda çalșan ve bu konuda eğitim görenlerin ablaki gelişim evrelerinin incelenmesi. (Yayınlanmamış Yüksek lisans tezi). Ankara Üniversitesi, Ankara

Farh, J., Zhong, C. \& Organ, D. W. (2004). organizational citizenship behavior in the people's republic of China. Organizational Science, 15 (2), 241-253.

Hatunoğlu, G. A. (2003). Farkh ablaki gelişim düzeylerinde bulunan üniversite öğrencilerinin kendilerinin ve toplumun ablak düreyini değerlendirmeleri ve psikolojik belirti düreylerinin karşılaşttrilması. (Yayınlanmamış Doktora tezi). Atatürk Üniversitesi, Erzurum. s.40

Ilgaz, S. \& Bilgili, T. (2006). Eğitim ve öğretimde etik. Atatürk Üniversitesi. Kazım Karabekir Eğitim Fakültesi Dergisi. 6 (14). 199-210.

Kant, E. (2007). Ethica, etik üzerine dersler.(Çeviren: O. Özügül). İstanbul: Pencere Yayınları.

Karataş, A. (2013).İlköğretim öğretmen adayları için meslek etiğinin önemi. Marmara Coğrafja Dergisi. o (28). 304-318. s. 28

Ketenci, T. (2008). Kant etiğinde duygululuğun eleştirisi. Felsefe ve Sosyal Bilimler Dergisi.5 (8). 35-55

Kılıç, M., Kaya, A., Yıldırım, N. \& Genç, G. (2004). Eğitimci gözüyle öğretmen ve öğrenci. XIII. Ulusal Ë̆gitim Bilimleri Kurultayı, İnönü Üniversitesi, Eğitim Fakültesi, Malatya, 6-9 Temmuz 2004

Köknel, Ö., (1996). Bireysel ve toplumsal şiddet. İstanbul: Altın Kitaplar Yayınevi. s. 81

Köse, M. \& Demir, E. (2016). Öğretmenlerin rol modelliği hakkında öğretmen görüşleri,” Akademike Bakuş Dergisi. 53, 38-57.

Kumar, R. (2011). Bilimsel araștırma yöntemleri. Araștırma yöntemleri (Çeviren: H. Atak). Ankara: Edge Akademi.

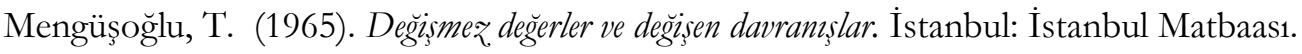

Merriam, S.B. (2013). Nitel araştırma: desen ve uygulama için bir rehber. S. Turan (Çeviri Ed.), Nitel araştırma nedir? (ss.1-55). Ankara: Nobel Akademik Yayıncillk s. 14

Miles, M.B. \& Huberman, A. M. (1994). Qualitative data analysis: An expanded sourcebook. Beverly Hills: Sage Publications.

Milli Eğitim Bakanlı̆̆1 (2017). Öğretmenlik mesleği genel yeterlikleri. Öğretmen Yetiştirme Genel Müdürlüğü. http://oygm.meb.gov.tr/www/ogretmenlik-meslegi-genel-yeterlikleri/icerik/39\# Erişim Tarihi: 07.11.2017.

Morrison, E.W. \& Pbelps, C.C. (1999). Taking charge at work: extrarote efforts lo initiate workplace change. Academy of Management Journal, 42 (4), 403-419.

Nietzsche, F. (2005).Ecco Homo. Kişi Nasıl Kendisi Olur. (Çeviren: O. Tuncay). İstanbul: Gün Yayıncllık.

Organ, D. W., (1988). Organizational citizenship behavior: The good soldier syndrome. Lexington Books/DC Heath and Com. 
Özdevecioğlu, M. (2003). Örgütsel vatandaşlık davranışı ile üniversite öğrencilerinin bazı demografik özellikleri ve akademik başarıları arasındaki ilişkilerin belirlenmesine yönelik bir araştırma, Erciyes Üniversitesi İktisadi ve İdari Bilimler Fakültesi Dergisi. 20, 117-135.

Öztik Türer, S. (2015). Profesyoneller için ablaki gelişim ölçeğinin geşerlilik ve güvenilirlike çalışması. (Yüksek lisans tezi). Atatürk Üniversitesi, Erzurum. s.17

Temli, Y., Şen, D. \& Akar, H.(2013). Elementary school teacher candidates' perceptions and definitions on morality and moral education. Eg̈itim ve Bilim 38 (168), 198-214.

Tokmak, N. \& Bakioğlu, A. (2009). Öğretmenlerin değer yargılarının eğitim süreçlerine etkisinin incelenmesi. M.Ü. Atatürk Eğitim Fakültesi Eğitim Bilimleri Dergisi. 30, 65-83.

Topbaş1, F. (2006). Okul öncesi dönem 6 yaş grubu çocuklarm törel (ablakkî) gelişiminde dramanm yeri ve önemi. (Yayınlanmamış Yüksek lisans tezi). Ankara Üniversitesi, Ankara. s.67

Ulusoy, K. \& Dilmaç, B. (2014). Değerler eğitimi. Ankara: Pegem A. Yayınları.

Uslu, B. \& Balc1, E. (2012).İlköğretim okulu öğretmenlerinin örgütsel vatandaşlı davranışları ile örgütsel iletişim algıları arasındaki ilişki. Kuram ve Uygulamada Eğitim Yönetimi.18 (3), 461-489.

Usta, A. (2011). Kuramdan uygulamaya kamu yönetiminde etik ve ahlak. Kahramanmaraş Sütçü Imam Üniversitesi İktisadi ve İdari Bilimler Fakültesi Dergisi. (1) 2, 39-50.

Van Scotter. J.R. \& Molowidlo, S.J. (1996). Interpersonal facililalion and job dedication as separate facels of contextual performance. Journal of Applied Psychology, 81(1), 525-531.

Yaşaroğlu, C. (2014). Sınıf öğretmenlerinin değerler eğitimine yönelik tutumlarının çeşitli değişkenler açısindan incelenmesi. International Journal of Social Science, 27, 503-515.

Yeşilyurt, E. \& Kilıç, M. E. (2014).Ortaokul öğrencilerinin algılarına göre öğretmenlerin etik değerlere uyma düzeylerinin değerlendirilmesi. EKEV Akademi Dergisi 18 (60). 471-486.

Yıldırım, A. \& Şimşek, H. (2013). Sosyal bilimlerde nitel araşstrma yöntemleri. (Genişletilmiş 9. Basker). Ankara: Seçkin Yayıncılık.

Yılmaz, B. (2005). Öğretmenlik nasıl bir meslektir? A. M. Sünbül (Ed.), Öğretmenin dünyası (ss. 7-22). Ankara: Mikro Yayınları

Zulliger, H. (1996). Cocuk vicdanı ve biæ: (Çeviren: K. Şipal). İstanbul: Cem Yayınevi. s.12

\section{Citation Information}

Demirkol, M. \& Kılıç, D. (2017). Sınıf Öğretmenlerinin Vicdan Alg1sı. Dicle Üniversitesi Ziya Gökkalp Eğgitim Fakültesi Dergisi, 32, 853-864. 